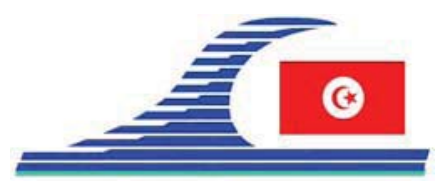

\author{
Conférence Méditerranéenne Côtière et Maritime \\ EDITION 1, HAMMAMET, TUNISIE (2009) \\ Coastal and Maritime Mediterranean Conference \\ Disponible en ligne - http://www.paralia.fr-Available online
}

\title{
ASDECO: Automated system for desalination plant dilution control
}

\author{
Andrés PAYO ${ }^{1}$, José Ma CORTÉS ${ }^{1}$, \\ Ana ANTORANZ ${ }^{1}$, José $M^{\text {a }}$ HERNANDEZ ${ }^{2}$
}

1. SIDMAR S. L. (Society for Marine Documentation and Research - Spain), Avda. País Valenciano, 22, E-03720 Benissa (Alicante), Spain. apayo@sidmar.es

2. TECNOMA S.A.C./ Antiga senda de Senent, 11-33 - 46023. Valencia, Spain. jhernandez@tecnoma.es

\begin{abstract}
:
There are different options for the brine disposal from seawater desalination plants, but ocean brine disposal is considered the least expensive one. Discharging strategies for negatively buoyant effluents (BLENINGER et al., 2006) has to be optimized in the design phase in order to meet the mandatory ambient standards. During the exploitation phase, it is becoming usual to have in place an alarm system to check the compliance of the ambient standards. An innovative approach is to proactively alert the plant managers before the ambient standards are exceeded to avoid damaging protected communities such as coral reefs or sea grass meadows. In this context the ASDECO project (Automated System for Desalination Dilution Control) was created. It is a three years research study (2007-2009) aimed to design and construct a prototype that analyzing in real time the effluent physical properties, environment assimilation capacity (physical, chemical and biological) will be able to "proactively" alert plant manager to avoid high salinity values in a nearby protected sea grass community. This innovative approach poses several challenges on the modelling of coastal brine discharges and the real time monitoring systems. The data measured by the monitoring system are used as input for a neural network model that predicts the salinity values at different places (NAVARRO et al., 2009). The measured variables used as an input were chosen based on previous field campaigns made at the study zone (PAYO et al., 2009). In this document we will describe in detail the setup of the monitoring network constructed at the Canal de Alicante desalting plant in the SE of Spain.
\end{abstract}

\section{Keywords:}

Brine discharge - ICZM - Oceanographic Buoys - Salinity - Real time monitoring

\section{Material and Methods}

DOI: $10.5150 / \mathrm{cmcm} .2009 .072-Y$ 


\subsection{Description of brine discharge and field site}

The study area is located along the Alicante coastline (SE Spain) where two seawater reverse osmosis (SWRO) desalination plants, hereinafter called Alicante I and Alicante II, are discharging brine directly into the nearshore through a shared open channel (Fig. 1). Each plant has a nominal freshwater production capacity of $66000 \mathrm{~m}^{3} /$ day with a conversion factor of $45 \%$. This represents a total salt water intake of $290000 \mathrm{~m}^{3} /$ day and a total brine discharge of $159500 \mathrm{~m}^{3} /$ day with a nominal salinity of $57.03 \mathrm{~g} / \mathrm{L}$. Alicante I was producing freshwater at maximum capacity and Alicante II was working at less than $50 \%$ of its capacity during the study period. The brine is diluted with sea water before being discharged. The seawater used for dilution is pumped from a superficial nearshore intake at the north side of the discharging channel. Four pumps, each one of $10800 \mathrm{~m}^{3} / \mathrm{h}$ of nominal capacity, are available for pumping the seawater to the location of brine discharge. The dilution ratios are adjusted by the plants managers in order to reduce the salinity values below 38.5 (PSU) in a nearby protected Posidonia oceanica meadows.

\subsection{Data acquisition and monitoring systems}

At a fixed location about $500 \mathrm{~m}$ away from the discharging point, wind, directional waves, current profile, near bottom current, conductivity and temperature among others have being measured continuously since November 2008 until present. Table 1 summarizes all the equipment used. Most of the sensors are calibrated by the manufacturer and only the YSI6560 conductivity sensor has to be calibrated periodically. A dataloger AXYS WatchManTM 500 gather and transmit all the measured data via GSM/GPRS to a central PC on land where data is stored. The sensors are powered by a 4 × 20 Watt solar panels and 4 x 100 Ah Sunlyte GNB 1000 deep cycle solar power batteries.

The telemetry system, power supply and sensors rack are all integrated in an AXYS WatchkeeperTM buoy. All cables and connectors are oceanographic underwater type. Separate sets of electrical cables are used externally to all sensors.

Figure 2 shows the set up of each sensor on the buoy. Wind is measured at $3.3 \mathrm{~m}$ above the free surface on the top of the mast. The TRIAXYS wave sensor is embedded inside the buoy hull at $0.5 \mathrm{~m}$ above the still water level. The SONTEK ADP current profiler and the YSI 6600V2 water quality sensors are located down looking and embedded on the buoy floating body inside of the moon-pools. The head of the ADP is at $1.5 \mathrm{~m}$ below the free surface, has a blanking distance of $0.3 \mathrm{~m}$ and have been configured to measure along 22 cells of $0.25 \mathrm{~m}$ cell size. The measuring cell of the YSI $6600 \mathrm{~V} 2$ is $1 \mathrm{~m}$ below the free surface. The FSI 2DACM+CTD were fixed at the bottom floor with the CTD sensor facing the ocean bottom and $10 \mathrm{~cm}$ above it. The current is measured at $0.3 \mathrm{~m}$ above the ocean bottom. 


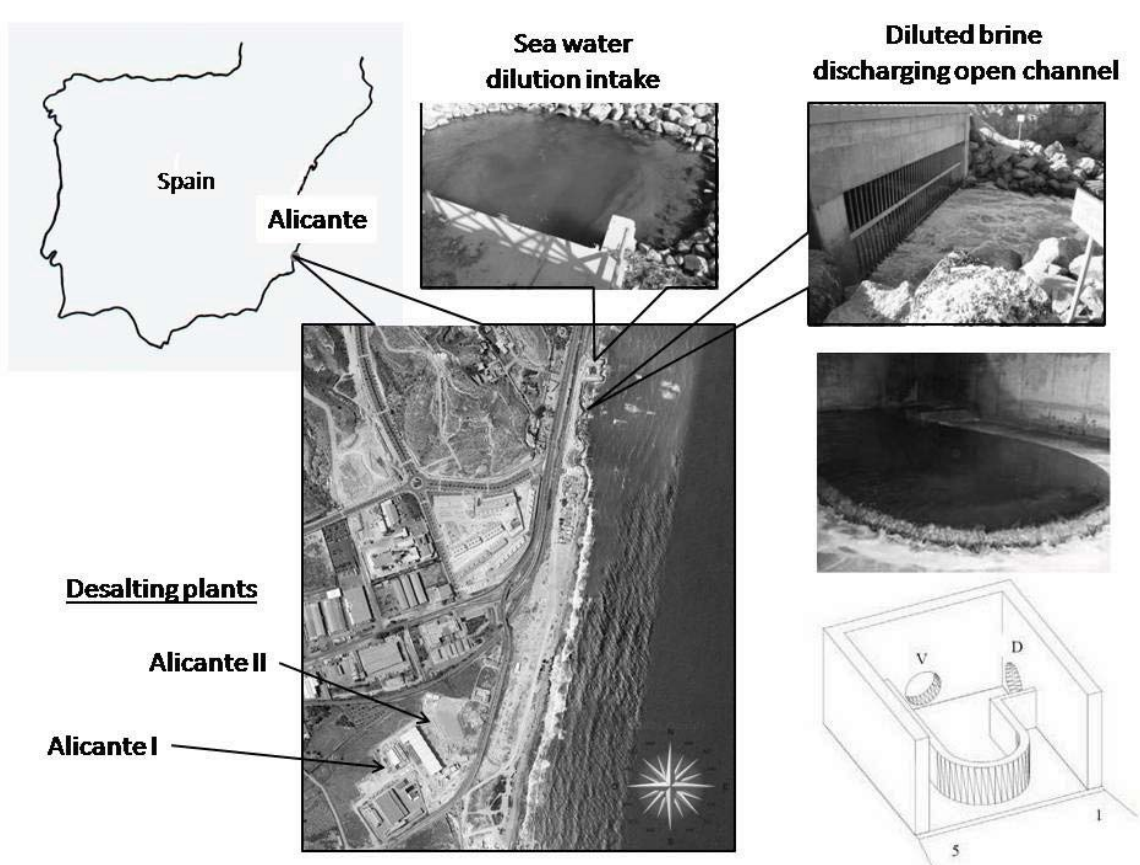

Figure 1. Location of the desalting plants Alicante I and Alicante II. The brine (V) and the sea water (D) are pumped thorough a $2 m$ diameter pipe into an open tank as shown in the right down corner panel. The mixed brine-sea water is discharged to the nearshore by overwahing the tank.

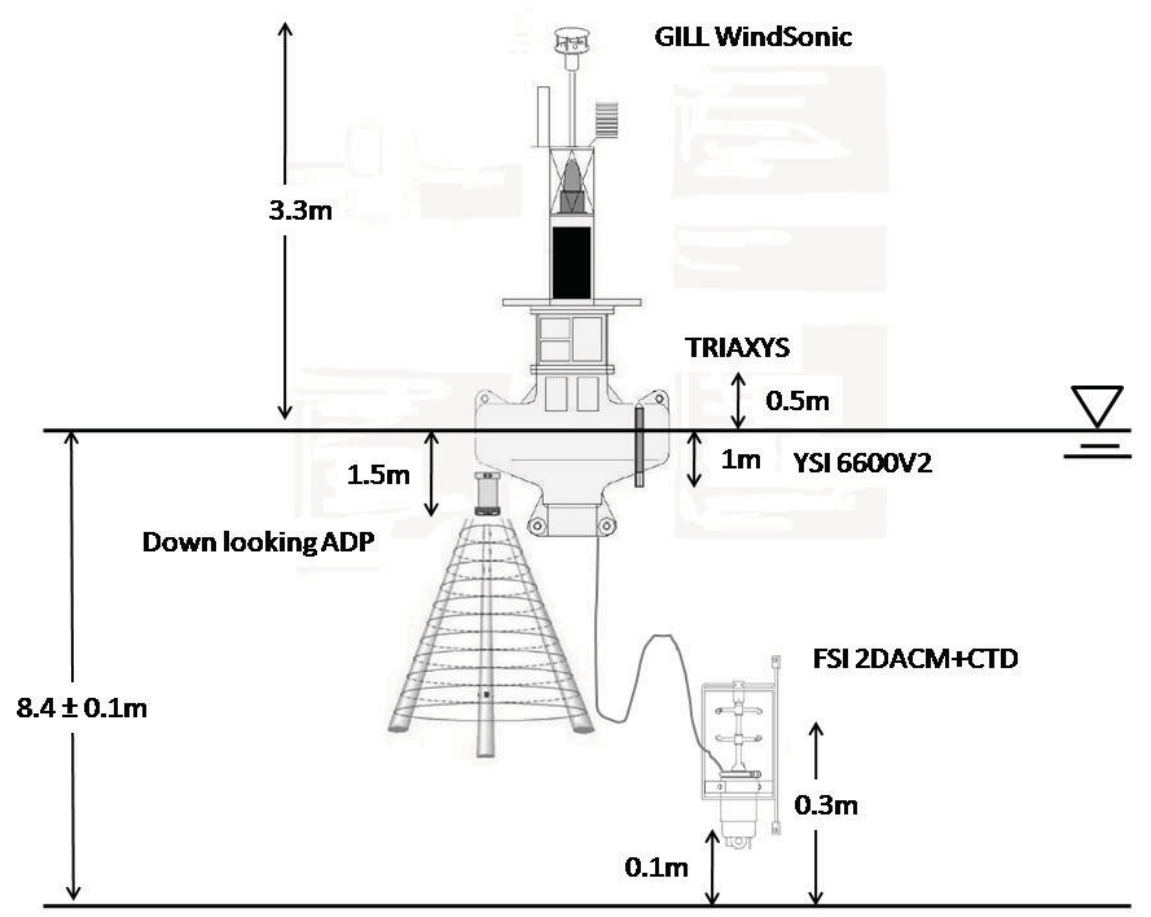

Figure 2. Set up of the SONTEK ADP, FSI 2DACM+CTD, YSI 6600V2 and GILL

Windsonic. All the sensors are powered from the Watchkeeper ${ }^{T M}$ buoy. 
Meilleures pratiques environnementales en ingénierie côtière et maritime

Table 1. Description of the equipment used at the fixed observation point.

\begin{tabular}{|c|c|c|c|c|}
\hline Parameter & Model & Accuracy & Resolution & Range \\
\hline Wind speed & \multirow{2}{*}{$\begin{array}{l}\text { GILL/ } \\
\text { Windsonic }\end{array}$} & $\% 2$ & $0.1 \mathrm{~m} / \mathrm{s}$ & $0-60 \mathrm{~m} / \mathrm{s}$ \\
\hline Wind direction & & $\pm 3^{\circ}$ & $1^{o}$ & $0-359^{\circ}$ \\
\hline Wave height & \multirow{2}{*}{$\begin{array}{l}\text { AXYS } \\
\text { TRIAXYS }\end{array}$} & $\% 2$ & $0.01 \mathrm{~m}$ & $\pm 20 m$ \\
\hline Wave direction & & $1^{o}$ & $1^{o}$ & $0-359^{\circ}$ \\
\hline \multirow[t]{2}{*}{ Current profile } & SONTEK & $\pm 1 \%$ & $\pm 0.1 \mathrm{~cm} / \mathrm{s}$ & $\pm 10 \mathrm{~m} / \mathrm{s}$ \\
\hline & \multicolumn{2}{|l|}{$A D P 1000 \mathrm{kHz}$} & \multicolumn{2}{|l|}{ Vertical $0.4 m-20$} \\
\hline \multirow[t]{2}{*}{ current velocity } & \multirow{5}{*}{$\begin{array}{l}F S I / 2 D A C M \\
+ \\
C T D\end{array}$} & $\% 2$ of readings or & $0.01 \mathrm{~cm} / \mathrm{s}$ & $0-600 \mathrm{~cm} / \mathrm{s}$ \\
\hline & & $1 \mathrm{~cm} / \mathrm{s}$ & & \\
\hline Conductivity & & $\pm 0.02 \mathrm{mS} / \mathrm{cm}$ & $0.001 \mathrm{mS} / \mathrm{cm}$ & $0-70 \mathrm{mS} / \mathrm{cm}$ \\
\hline Temperature & & $\pm 0.03^{\circ} \mathrm{C}$ & $0.001{ }^{\circ} \mathrm{C}$ & $-5^{\circ}-32^{\circ} \mathrm{C}$ \\
\hline Water level & & $\pm 0.3 \%$ full scale & $\pm 0.01 \%$ full scale & $0-200 \mathrm{dBar}$ \\
\hline \multirow[t]{3}{*}{ Surface Salinity } & $Y S I$ & $\pm 1 \%$ of reading or & $0.01 p p t$ & $0-70 p p t$ \\
\hline & 6560 integrated & 1ppt whichever & & \\
\hline & on YSI6600V2 & greater & & \\
\hline
\end{tabular}

\section{Conclusions}

In order to proactively alert about the compliance of the ambient standards nearby a coastal brine disposal a complex monitoring system has been installed. During the neural network training phase a complete set of oceanographical variables are required to indentify the predominant mixing forcing mechanisms. During the exploitation phase, real time data transmission and the capacity of remotely change the configuration of the measuring instrument is found critical to timely adapt to changes in the brine properties, environment and ambient standards regulations.

\section{References}

BLENINGER T., JIRKA G.H., WEITBRECHT V. (2006). Optimal discharge configuration for brine effluents from desalination plants. Proc. DME (Deutsche MeerwasserEntsalzung), Congress, 04.-06.04.2006, Berlin.

NAVARRO M., MOLINA R., MARTIN M., HERNANDEZ J., HERNÁNDEZ A. (2009). Development of a neuro fuzzy modelling tool for a decision support system in desalination in Coastal Zones. EDS, Conference for the Desalination for the Environment clean water energy, Baden-Baden, Germany.

PAYO A., CORTÉS J., MOLINA R. (2009). Effect of wind and waves on a nearshore brine discharge dilution in the East Coast of Spain. EDS, Conference for the Desalination for the Environment clean water energy, Baden-Baden, Germany. 